\title{
An Increase in Learning Outcome Students is Through The Development of Archive E-Module Based on The Flipbook With Discovery Learning Model
}

\author{
Indri Isnaeni ${ }^{1}$, Yuli Agustina ${ }^{2}$ \\ Department of Management, Universitas Negeri Malang \\ E-mail: yuli.agustina.fe@um.ac.id
}

\begin{abstract}
The purposes of this research are to produce, to know the validation, and effectiveness of e-module based flipbook with Discovery Learning Model that is produced by researcher. The product resulted from this research and development is e-module based flipbook with Discovery Learning Model in archival with basic competencies Applying Archive Maintenance Procedures. This research and development uses Lee \& Owens consisting of 4 steps: (1) Assessment/Analysis; (2) Design; (3) Development and Implementation; (4) Evaluation. Subjects of this research and development are product technology experts, material experts, and learners. The average product technology expert validation is 95.4 percent, material expert validation is 97 percent, and student validation is 91.6 percent. The emodule is effective to be used in learning activities in the classroom as indicated by the normalized gain test $>0.7$ of 0.75 .
\end{abstract}

Keywords: e-module, flipbook, discovery learning, learning outcomes

\section{INTRODUCTION}

The 2013 Curriculum is one of the reforms in the sector of education conducted by the government to improve the quality of education in Indonesia (Retnawati et al., 2016). The problems experienced in the world of education in Indonesia are the low ability of students to process information, make generalizations, solve problems, and draw conclusions on data (Indratno, 2013). One of the factors causing the achievement of Indonesian education very low is the learning process in the schools was too academic oriented through memorization, repetitive training, structured instruction, and one-way teaching (Kuyumcu, 2012; Miller, 2003; Saborit et al., 2016; Smith et al., 2018). The orientation directs students only to get good score and produce short-term memory skills (Indratno, 2013).

Learning based on the 2013 curriculum is strongly recommended using a scientific approach namely organizing learning experiences in a logical sequence including observing, asking, gathering information, reasoning, and communicating (Permendikbud, 2016). To strengthen the implementation of the scientific approach is needed for disclosure-based learning or research (Permendikbud, 2016). Discovery learning is a learning model that encourages students to learn by themselves (Baharuddin \& Wahyuni, 2015).

The previous research was conducted by Balim (2009), proves that the success and learning skills of students will increase well when they apply Discovery Learning Model than traditional learning model. The advantage of 
using Discovery Learning Model is to help students gain knowledge individually in order that it can be understood and settled in their minds, can arouse students' motivation and learning passion to study harder, provide opportunities to develop and progress accordingly with their own abilities and interests, and strengthen and increase self-confidence with the process of finding themselves because learning is centered on students with teacher's very limited roles (DeDonno, 2016; Kistner et al., 2016; Künsting et al., 2013).

Whereas, the weaknesses of the Discovery Learning Model are that students must have mental readiness and maturity, students must be brave and willing to know their surrounding conditions well. In the fact the class condition is fat, so this method will not achieve satisfactory result. Teachers and students who are very accustomed to using old style PBM, this discovery method will disappoint, discovery process is too concerned with the process of understanding, less attention to the development of attitudes and skills for students (DeDonno, 2016).

Learning activities in the classroom cannot be separated from teaching material, module is one of the teaching materials that can encourage students to learn actively and independently because they are equipped with learning instructions (Ministry of National Education, 2008). On the other hand, the availability of the teaching material in the class is still very limited, besides its amount does not meet the needs of students, the available teaching material is only limited to convey the material and are less able to encourage students to find concepts for themselves independently.

The use of technology in learning activities is still limited to search for material. The use of technology has not yet been used for media or teaching materials. Even though based on Government Regulation No. 103 of 2014, the implementation of classroom learning is recommended to use technology to improve learning efficiency. Based on these problems, the development of a flipbook-based Archive e-module with discovery learning learning models is important to be done.

\section{METHOD}

The method that is used in the research and development of Lee and Owens (2014) consists of stages (1) Analysis, (2) Product Design, (3) Development and Implementation, (4) and Evaluation. The analysis phase is carried out through two stages, namely need analysis and front end analysis. The needs analysis aims to find out the problems faced in the implementation of learning in the classroom, while the front end stage aims to analyze the solutions to the problems posed by researchers. The product design phase produces the product story board and research instruments that are needed including validation sheets (for product technology, material experts, and users in limited groups), observation sheet, and post test questions for students. The evaluation phase is done gradually. The first stage is formative evaluation which aims to determine the feasibility of the e-module produced based on the validator's assessment. Second, the summative evaluation is done by comparing the scores of students before and after using an e-module 
that aims to measure the effectiveness of the e-module produced. The subjects of this research and development are technology experts who are lecturers of Technology Education at Universitas Negeri Malang and Archival teachers at SMK Negeri 1 Boyolangu as material expert validators, 9 students as user validators in a limited group, and 36 students as subjects for emodule effectiveness testing.

\section{RESULTS \& DISCUSSION Result}

The validation of flipbook-based e-module with Discovery Learning Model was carried out by product technology experts, material experts, and 9 students as users in a limited group. The results of the instrument calculation of product technology validation assessment of e-module obtained results of 95.4 percent classified as very valid. The results of the calculation of the instrument assessment of the material validation of the e-module that has been done by the material validator obtained 97 percent and classified as very valid. The results of the validation carried out by users in a limited group get a result of 91.6 percent, this indicates that the e-module produced can be said very valid based on the users. The overall validation is 94.67 percent, this result indicates that e-module produced by the researcher is said suitable to be applied in classroom learning activities.

To measure e-module effectiveness, researcher uses the normalized gain formula by comparing the values before and after students used a flipbook-based Archive e-module with discovery learning model. Calculation of normalized gain score obtained $>0.70$, which is equal to 0.75 . It means that the e-module produced is effective to improve students' cognitive learning outcomes. Based on the results of the pretest and posttest, researcher can also obtain results that the average of pretest score is 78.3 with a percent of completeness of 66.67 percent, while the average posttest is 91.4 with a percentage of completeness of 97.22 percent. Hence, overall the average value of students have increased after using the e-module (See Figure 1).

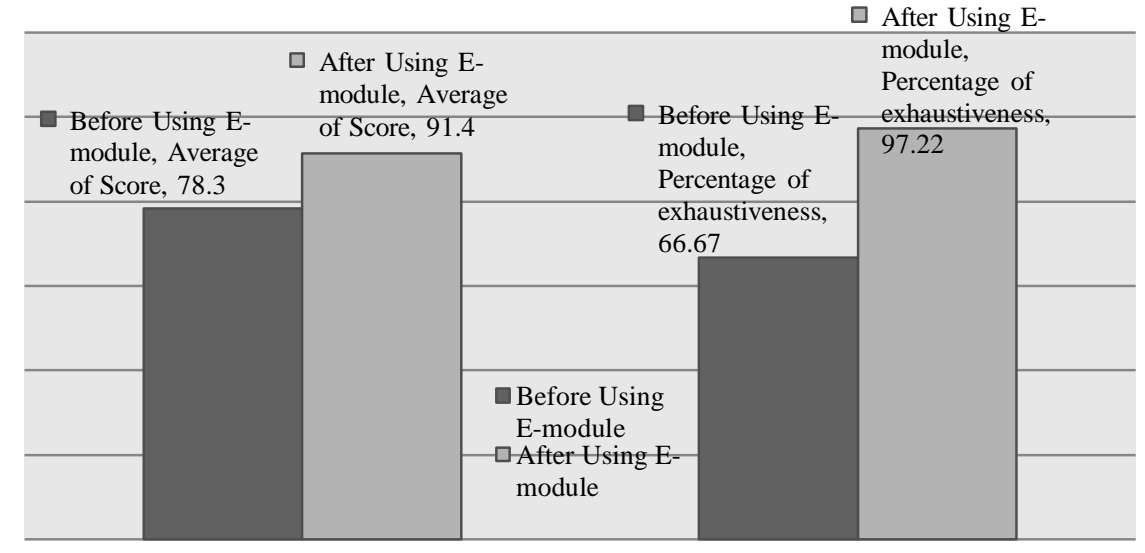

Figure 1. The average of Score and Percentage of Students' exhaustiveness Classrooms X Office Management 3 Vocational School State 1 Boyolangu 


\section{Discussion}

This research and development produces a flipbook-based Archive e-module with a learning discovery learning model on the basic competencies of Implementing Archive Maintenance Procedures. The results of validation by the validator show that the e-module includes the category "very valid and feasible" used in learning activities. The results of the validation by product technology experts indicate that the criteria are "very valid", the material experts are "very valid", and users are limited to "very valid" criteria. In addition, the researcher revised the suggestion of the validator delivered by written and oral. the posttest results conducted showed that the e-modules produced included effective categories used in learning activities. The e-module produced is proven to be proven by improving student learning outcomes compared to the value before using the e-module.

\section{CONCLUSION}

Based on the research and development, it can be concluded that flipbookbased e-module with Discovery Learning Model which is developed by valid researchers based on the results of expert validation. In addition, flipbookbased e-module with Discovery Learning Model is also effectively used in learning activities and improve student learning outcomes. Flipbook-based Emodule and Discovery Learning Model are recommended to be used as teaching materials in classroom learning activities. In learning activities, the teacher does not explain the material with lectures but acts as a facilitator for students. Teachers are advised to be able to encourage students to actively find their own knowledge with the help of flipbook-based e-module with Discovery Learning Model.

\section{REFERENCES}

Baharuddin \& Wahyuni, E.N. 2015. Teori Belajar dan Pembelajaran. Yogyakarta: Ar-Ruzz Media (Indonesian Origin)

Balim, A.G., 2009. The Effect of Discovery Learning on Student's Succes and Inquiry Learning Skills. Eurasian Journal of Educational Research, 35,1-20.

DeDonno, M.A., 2016. The influence of IQ on pure discovery and guided discovery learning of a complex real-world task. Learning and Individual Differences 49, 11-16. https://doi.org/10.1016/j.lindif.2016.05.023

Government Regulation No. 103 of 2014 concerning Learning in Basic Education and Secondary Education. (Indonesian Origin) 
Hanafiah, N. \& Suhana, C. 2009. Konsep Strategi Pembelajaran. Bandung: PT Refika Aditama (Indonesian Origin)

Indratno, A.F.T., 2013. Menyambut Kurikulum 2013. Jakarta: Kompas

Kistner, S., Vollmeyer, R., Burns, B.D., Kortenkamp, U., 2016. Model development in scientific discovery learning with a computer-based physics task. Computers in Human Behavior 59, 446-455. https://doi.org/10.1016/j.chb.2016.02.041

Künsting, J., Kempf, J., Wirth, J., 2013. Enhancing scientific discovery learning through metacognitive support. Contemporary Educational Psychology 38, 349-360. https://doi.org/10.1016/j.cedpsych.2013.07.001

Kuyumcu, F.N., 2012. The Importance of "Art Education" Courses in the Education of Prospective Teachers. Procedia - Social and Behavioral Sciences, The World Conference on Design, Arts and Education (DAE2012), May 1-3 2012, Antalya, Turkey 51, 474-479. https://doi.org/10.1016/j.sbspro.2012.08.192

Lee W. M. \& Owens, L. D. 2014. Multimedia-Based Instructional Design. San Fransisco: Permission of Pfeiffer

Miller, G.A., 2003. The cognitive revolution: a historical perspective. Trends in Cognitive Sciences 7, 141-144. https://doi.org/10.1016/S13646613(03)00029-9

Ministry of National Education. 2008. Penulisan Modul. Jakarta: Departemen Pendidikan Nasional. (Indonesian Origin)

Minister of Education and Culture Regulation Number 8 of 2016 concerning Books used by Education Units. (Indonesian Origin)

Saborit, J.A.P., Fernández-Río, J., Cecchini Estrada, J.A., Méndez-Giménez, A., Alonso, D.M., 2016. Teachers' attitude and perception towards cooperative learning implementation: Influence of continuing training. Teaching and Teacher Education 59, 438-445. https://doi.org/10.1016/j.tate.2016.07.020

Smith, T.E., Rama, P.S., Helms, J.R., 2018. Teaching critical thinking in a GE class: A flipped model. Thinking Skills and Creativity 28, 73-83. https://doi.org/10.1016/j.tsc.2018.02.010

Retnawati, H.,Hadi, S., Nugraha , A.C., 2016. Vocational High School Teachers' Difficulties in Implementing the Assessment in Curriculum 2013 in Yogyakarta Province of Indonesia. International Journal of Instruction, v9 n1 p33-48 Jan 2016 